\title{
Mosaicism in clinical genetics
}

\author{
Heather C. Mefford \\ Center for Pediatric Neurological Disease Research, St. Jude Children's Research Hospital, Memphis, \\ Tennessee 38105, USA
}

\begin{abstract}
Genetic mosaicism is the state in which there are two or more different sets of cells in a single individual because of one or more postzygotic mutations, and its importance in clinical genetics has long been recognized (Hall, Am J Hum Genet 43: 355 [1988]). In this Perspective, a paper in this special issue on mosaicism from Cook et al. (Cold Spring Harb Mol Case Studies 7: a006125 [2021]) is discussed.
\end{abstract}

Corresponding author:

heather.mefford@stjude.org

(c) 2021 Mefford This article is distributed under the terms of the Creative Commons Attribution-NonCommercial License, which permits reuse and redistribution, except for commercial purposes, provided that the original author and source are credited.

Published by Cold Spring Harbor Laboratory Press

doi:10.1101/mcs.a006162
Even before we had the ability to detect genetic mosaicism, clinical features such as hemihypertrophy or patchy skin findings were recognized as physical clues suggesting an underlying somatic mosaic variant. Karyotype analysis of cultured cells was one of the first tests that allowed the identification of mosaic chromosomal abnormalities. Clinical observations such as segmental neurofibromatosis suggested single-gene somatic variation, later confirmed by analysis of affected tissue when Sanger sequencing developed. Similarly, germline (gonadal) mosaicism for a single-gene disease in an unaffected parent was first suggested by the rare clinical observation of multiple affected children with a severe, presumably dominant disorder when both parents were phenotypically normal.

Fast-forward to 2021. The suite of tools that can be used to detect genetic mosaicismand their sensitivity-has grown substantially. Sanger sequencing confirmed many of the early predictions about mosaicism made by clinical observations, but levels of mosaicism below $\sim 10 \%-20 \%$ are difficult to reliably detect. Over the past decade, much more sensitive tools have emerged. Next-generation sequencing (NGS) offers the advantage over Sanger sequencing of producing discrete sequence reads that can be counted, and the fraction of reads with a specific variant can be calculated, reflecting the proportion of variant-carrying cells in the affected tissue. Furthermore, the depth of coverage-or total number of reads generated — can be adjusted to increase sensitivity. Droplet digital polymerase chain reaction (ddPCR) is a method to interrogate specific variants and allows the detection of extremely low levels of mosaicism. Single-nucleotide polymorphism (SNP) microarrays can detect mosaic copy-number variants. Application of these tools in research and clinical settings over the past decade has established an important role for mosaicism in clinical genetics.

In this issue, Cook et al. (2021) report the frequency of mosaic pathogenic variants in a cohort of 500 individuals with suspected genetic disease who had trio exome or genome sequencing for diagnostic purposes through the CAUSES study. They identify 12 (2.4\%; 4.6\% of families who received a genetic diagnosis) families in which the causative genetic variant is mosaic in the proband $(n=3)$ or in a parent $(n=9)$. Their results highlight the various ways that mosaicism can present in families with genetic disease. Although they only identified three mosaic probands, their results confirm that the level of mosaicism detected by clinical sequencing of accessible tissue (often blood or saliva) cannot be used to predict severity. Of the three probands with mosaic pathogenic variants, one presented with physical asymmetry 
Competing Interest Statement The authors have declared no competing interest. suggestive of mosaicism and had a milder overall presentation of disease than expected (46\% variant allele frequency [VAF] for X-linked CASK variant in a male). In the other two cases, the phenotype of the mosaic individual was not distinguishable from the expected phenotype; one individual had a fairly low level of mosaicism (VAF of $13 \%$ in autosomal gene TRIO), whereas the other had a high level of mosaicism (VAF of $90 \%$ in X-linked SLC6A8 in a male). Nine parents (1.8\% of families; $3.4 \%$ of families with a diagnosis) were found to harbor the same pathogenic variant as their affected child, with VAFs ranging from 1.6\% to $18 \%$. Only one parent had mild manifestations of disease, whereas the other eight had no clinical features.

The frequency of mosaicism in genetic disorders is likely underestimated in this study for several reasons. First, the study was not designed specifically to detect mosaicism. Clinical genome sequencing is performed at approximately one-third the sequence coverage of exome sequencing. This limits the detection of low-level mosaicism; indeed, 9/12 mosaic variants in this study were detected by exome sequencing. Exome sequencing may still miss very low-level mosaicism, depending on sequence depth. Second, the sequence data were generated using blood-derived DNA, which would prevent detection of any disease-causing variant that is only present in affected tissue(s). There are numerous examples of mosaic variants limited to affected tissues, including Proteus syndrome (Lindhurst et al. 2011), PIK3CA-related overgrowth syndrome (Mirzaa et al. 2016), hemimegalencephaly (Lee et al. 2012), and vascular malformations (Luks et al. 2015) among others. Germline mosaicism is a special consideration of mosaicism that may be tissue-restricted (Yang et al. 2021). In this study, a mosaic parent was identified in $3.4 \%$ of families with a genetic diagnosis, a rate similar to several other studies (Myers et al. 2018; Møller et al. 2019), but a parent with mosaicism restricted to the germline would be missed.

Identifying mosaicism in a proband or a parent has important implications for recurrence risk counseling in the clinical setting. Families who have a child with a de novo pathogenic variant have traditionally been counseled that recurrence risk is $\sim 1 \%$. This is an empirical risk estimate that takes into account the infrequent possibility of germline parental mosaicism, but detection of the same pathogenic variant in a parent can significantly increase the recurrence risk (up to 50\%). On the other hand, if the de novo pathogenic variant arose postzygotically in the proband, the recurrence risk truly is $\sim 0 \%$. Differentiating between these two scenarios can have significant clinical impact.

The ongoing challenge for clinicians and genetic testing providers is to determine when to suspect mosaicism and which test to use to detect it. The study by Cook and colleagues was not designed specifically to detect mosaicism, but their approach is representative of current diagnostic genetic testing using NGS and clearly shows the importance of considering mosaicism when interpreting sequence results. Mosaicism may play an even greater role in genetic disease than we are able to detect today. Combining clinical judgment to select potentially mosaic individuals with innovative genetic approaches to detect variants will reveal the full spectrum and impact of mosaicism in genetic disease.

\section{REFERENCES}

Cook CB, Armstrong L, Boerkoel CF, Clarke LA, du Souich C, Demos MK, Gibson WT, Gill H, Lopez E, Patel MS, et al. 2021. Somatic mosaicism detected by genome-wide sequencing in 500 parent-child trios with suspected genetic disease: clinical and genetic counseling implications. Cold Spring Harbor Mol Case Stud 7: a006125. doi:10.1101/mcs.a006125

Lee JH, Huynh M, Silhavy JL, Kim S, Dixon-Salazar T, Heiberg A, Scott E, Bafna V, Hill KJ, Collazo A, et al. 2012. De novo somatic mutations in components of the PI3K-AKT3-mTOR pathway cause hemimegalencephaly. Nat Genet 44: 941-945. doi:10.1038/ng.2329 
Lindhurst MJ, Sapp JC, Teer JK, Johnston JJ, Finn EM, Peters K, Turner J, Cannons JL, Bick D, Blakemore L, et al. 2011. A mosaic activating mutation in AKT1 associated with the Proteus syndrome. N Engl J Med 365: 611-619. doi:10.1056/NEJMoa1104017

Luks VL, Kamitaki N, Vivero MP, Uller W, Rab R, Bovee JV, Rialon KL, Guevara CJ, Alomari Al, Greene AK, et al. 2015. Lymphatic and other vascular malformative/overgrowth disorders are caused by somatic mutations in PIK3CA. J Pediatr 166: 1048-1054 e1041-e1045. doi:10.1016/j.jpeds.2014.12.069

Mirzaa G, Timms AE, Conti V, Boyle EA, Girisha KM, Martin B, Kircher M, Olds C, Juusola J, Collins S, et al. 2016. PIK3CA-associated developmental disorders exhibit distinct classes of mutations with variable expression and tissue distribution. JCl Insight 1: e87623. doi:10.1172/jci.insight.87623

Møller RS, Liebmann N, Larsen LHG, Stiller M, Hentschel J, Kako N, Abdin D, Di Donato N, Pal DK, Zacher P, et al. 2019. Parental mosaicism in epilepsies due to alleged de novo variants. Epilepsia 60: e63-e66. doi:10 1111/epi.14601

Myers CT, Hollingsworth G, Muir AM, Schneider AL, Thuesmunn Z, Knupp A, King C, Lacroix A, Mehaffey MG, Berkovic SF, et al. 2018. Parental mosaicism in "de novo" epileptic encephalopathies. N Engl J Med 378: 1646-1648. doi:10.1056/NEJMc1714579

Yang X, Breuss MW, Xu X, Antaki D, James KN, Stanley V, Ball LL, George RD, Wirth SA, Cao B, et al. 2021. Developmental and temporal characteristics of clonal sperm mosaicism. Cell 184: 4772-4783 e4715. doi:10.1016/j.cell.2021.07.024 


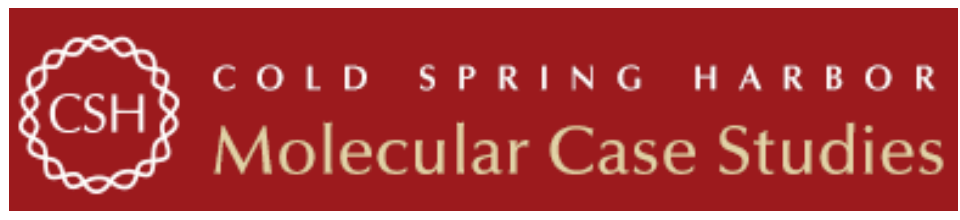

\section{Mosaicism in clinical genetics}

Heather C. Mefford

Cold Spring Harb Mol Case Stud 2021, 7: a006162

Access the most recent version at doi: $10.1101 /$ mcs.a006162

References This article cites 8 articles, 1 of which can be accessed free at: http://molecularcasestudies.cshlp.org/content/7/6/a006162.full.html\#ref-list-1

License This article is distributed under the terms of the Creative Commons Attribution-NonCommercial License, which permits reuse and redistribution, except for commercial purposes, provided that the original author and source are credited.

Email Alerting Receive free email alerts when new articles cite this article - sign up in the box at the Service top right corner of the article or click here. 